\title{
ВЛИЯНИЕ ПРОИЗВОДНЫХ ХИНАЗОЛИН-4(3Н)-ОНА НА ЖИЗНЕСПОСОБНОСТЬ ПЕРИТОНЕАЛЬНЫХ МАКРОФАГОВ МЫШИ
}

\author{
А.В. Борисов ${ }^{1,2}$, Е.В. Соколова ${ }^{3}$, А.А. Озеров ${ }^{4}$, И.Н. Тюренков ${ }^{5}$ \\ ${ }^{1}$ Научный центр инновационных лекарственных средств с опытно-промышленным \\ производством, ВолгГМУ, 400131, Россия, Волгоград, ул. Новороссийская, д.39. \\ 2Лаборатория патоморфологии, ВМНЦ, \\ 400131, Россия, Волгоград, площадь Павших Борцов, д. 1. \\ ${ }^{3}$ Кафедра фармакологии и биоинформатики, ВолгГМУ, \\ 400131, Россия, Волгоград, площадь Павших Борцов, д. 1. \\ ${ }^{4}$ Кафедра фармацевтической и токсикологической химии, ВолгГМУ, \\ 400131, Россия, Волгоград, площадь Павших Борцов, д. 1. \\ ${ }^{5}$ Кафедра фармакологии и фармации Института НМФО, ВолгГМУ, \\ 400131, Россия, Волгоград, площадь Павших Борцов, д. 1.
}

DOI: 10.19163/MedChemRussia2021-2021-476

E-mail: borissow1978@rambler.ru

Хиназолин, хиназолиноны и их производные представляют собой уникальный класс биологически активных азотсодержащих гетероциклических соединений с разнообразными терапевтическими и фармакологическими свойствами. [1]. Однако, для оценки их терапевтического потенциала необходимо изучить возможное негативное влияние на жизнеспособность клеток. Цель данной работы заключалась в изучении потенциальной цитотоксичности 4 производных хиназолин-4(3Н)-она с гуанидиновым заместителем под лабораторными шифрами VMA-13-10, VMA-13-15, VMA-13-16 и VMA-13-17. Исследование проводилось на культуре перитонеальных макрофагов мыши [2] с использованием комбинации методов оценки клеточной цитотоксичности: МТТ-теста [3] и анализа высвобождения лактатдегидрогеназы [4]. После совместной 72 часовой инкубации клеток с синтезированными веществами в конечных концентрациях 0,1; $1 ; 10$ и 100 мкМ оценивали жизнеспособность клеток вышеперечисленными методами.

Полученные результаты показали, что жизнеспособность клеток после экспозиции с изучаемыми веществами во всех концентрациях составляла 100 \% от уровня жизнеспособности интактных клеток. На основании полученных данных можно сделать вывод, что все исследуемые вещества не оказывают цитотоксическое действие на перитонеальные макрофаги мыши.

\section{Литература}

[1] Hameed, A., Al-Rashida, M., Uroos, M. et al. Quinazoline and quinazolinone as important medicinal scaffolds: a comparative patent review (2011 - 2016), Expert Opinion on Therapeutic Patents. 2018. 28:4, 281 - 297, doi: 10.1080/13543776.2018.1432596.

[2] Avijit Ray, Bonnie N. Dittel. Isolation of Mouse Peritoneal Cavity Cells. J. of Visual. Exp. 2010, 35-1488.

[3] Hassanzadeh F, Sadeghi-Aliabadi H, Nikooei S, Jafari E, Vaseghi G. Synthesis and cytotoxic evaluation of some derivatives of triazole-quinazolinone hybrids. Res Pharm Sci. 2019. 14(2), 130-137. doi: 10.4103/1735-5362.253360.

[4] Kumar, P., Nagarajan, A., Uchil, P.D. (2018). Analysis of Cell Viability by the Lactate Dehydrogenase Assay. Cold Spring Harbor Protocols. 2018 (6). doi:10.1101/pdb.prot095497.

$$
-476-
$$

